\title{
Is There a Role for Sex Hormone Receptors in Head-and-neck Cancer? Links with HPV Infection and Prognosis
}

\author{
CLARIANO PIRES DE OLIVEIRA NETO ${ }^{1}$, HAISSA OLIVEIRA BRITO ${ }^{1}$, \\ RUI MIGUEL GIL DA COSTA ${ }^{1,2,3,4}$ and LUCIANE MARIA OLIVEIRA BRITO ${ }^{1}$ \\ ${ }^{1}$ BTMA, Post-Graduate Programme in Adult Health (PPGSAD), Federal University of Maranhão, São Luis, Brazil; \\ ${ }^{2}$ CITAB, University of Trás-os-Montes e Alto Douro, UTAD, Vila Real, Portugal; \\ ${ }^{3}$ Molecular Oncology and Viral Pathology Group, \\ Portuguese Institute of Oncology in Porto Research Centre (CI-IPOP), Porto, Portugal; \\ ${ }^{4}$ LEPABE, Chemical Engineering Department, University of Porto Faculty of Engineering (FEUP), Porto, Portugal
}

\begin{abstract}
Background/Aim: Head-and-neck squamous cell carcinoma (HNSCC) is the fifth most common cancer in the world and human papillomavirus (HPV) is an important risk factor for this neoplasm. Recent studies showed an association between sex hormone receptors and pathogenesis and/or prognosis in patients with HNSCC. The aim of this study was to clarify the expression patterns of sex hormone receptors in $H P V$-positive and HPV-negative HNSCC and their associations with tumour biopathology and biological behaviour. Materials and Methods: Scientific literature indexed in PubMed about sex hormone receptors in HNSCC was retrieved and critically analyzed, to obtain an overview of expression patterns and their possible implications for tumour biopathology and prognosis. Results: Sex hormone receptors were more frequently detected in oropharyngeal tumours compared with HNSCC from other locations. ER $\alpha$ was associated with HPV-positive tumours. The androgen and progesterone receptors were associated with poor patient prognosis. Estrogen receptor alpha $(E R \alpha)$ is implicated in the biopathology of HNSCC in different ways, by promoting DNA hypermutation and facilitating HPV integration thus contributing to an immunogenic phenotype, but also by
\end{abstract}

This article is freely accessible online.

Correspondence to: Clariano Pires de Oliveira Neto, Programa de Pós Graduação em Saúde do Adulto (PPGSAD), Universidade Federal do Maranhão (UFMA), Avenida dos Portugueses, 1966, São Luis, Maranhão, Brasil. Tel: +55 9832729520, e-mail: clarianoneto@gmail.com

Key Words: HPV, head-and-neck cancer, estrogen receptor $\alpha$, estrogen receptor $\beta$, progesterone receptor, review. cooperating with the epithelial growth factor receptor (EGFR) to promote resistance to therapy. Conclusion: The expression of sex hormone receptors may be of prognostic value in specific tumour subgroups, but the use of hormonal therapies for HNSCC is still not in close sight.

Head-and-neck cancer comprises a group of malignancies affecting multiple sites including the oral cavity, the oropharynx, nasopharynx, hypopharynx, larynx and the salivary glands. Histologically, these lesions are most commonly squamous cell carcinomas (HNSCC) (1). An estimated 650,000 new cases occur yearly worldwide, along with 330000 deaths from HNSCC (2). In the USA, HNSCC corresponds to $3 \%$ of all cancers with approximately 53,000 new cases and 10,800 deaths yearly. Males seem to be at higher risk, with a male to female ratio varying between 2:1 and 4:1 (3). Classically, alcohol and tobacco consumption have been identified as major risk factors for developing $\operatorname{HNSCC}(4,5)$. Recently, infection with high-risk human papillomavirus (HPV) has been recognized as a risk factor for developing HNSCC (6). HPVpositive HNSCC is preferentially located at oropharyngeal sites, especially the tonsils and the tongue base, and shows distinguishing clinico-pathological features (7). Other risk factors for developing HNSCC include dietary or workplace exposure to environmental toxicants and genetic predisposition (8-10). Between 2005 and 2014, the incidence of HPV-positive HNSCC increased by $3 \%$ while that of classical lesions decreased by $2 \%$ (11). The increasing incidence of HPVpositive HNSCC motivated a significant effort to understand the biopathology of these lesions and adapt the current therapeutic approaches (12). A number of markers is currently in use or under study for identifying these lesions (e.g., immunohistochemistry for $\mathrm{p} 16^{\mathrm{INK} 1 \mathrm{~A}}$ ) or to predict response to 
specific therapies (e.g., infiltration of T lymphocytes to predict response to immune checkpoint inhibitors) $(13,14)$. However, the role of hormonal receptors in HNSCC remains poorly defined.

Hormonal receptors play a major role in some malignancies like breast (15) and prostate (16) cancers and have also been implicated in HPV-driven lesions like cervical cancer $(17,18)$. Multiple studies have addressed the expression patterns of hormonal receptors in HNSCC, as well as their association with HPV and their potential clinical significance, but the data concerning this subject remains dispersed and difficult to interpret. The present review brings together those data, contributing to clarify the expression patterns of hormonal receptors in HPV-positive and HPVnegative HNSCC. The contributions of hormonal receptors for the biopathology of these cancers and their potential impact on therapy are also discussed. For these purposes, PubMed-indexed research articles and reviews were retrieved and critically analyzed. Preference was given to recent literature published between 2015 and 2020, but older studies were included whenever useful to define the timeline of research in this field.

\section{HPV-positive Versus HPV-negative HNSCC}

Classical HNSCC is strongly associated with tobacco and alcohol consumption: data from the International Head and Neck Cancer Epidemiology Consortium (INHANCE) show that cigarette smoking increases HNSCC risk by $50 \%$ and smoking more than 5 cigarettes per day increases HNSCC risk by over two-fold (19). Alcohol is another well-known risk factor for HNSCC, oesophageal and gastric cancer, and cooperates with tobacco to increase HNSCC risk (20-22). Genetic polymorphisms have been suggested to increase the risk of HNSCC associated with alcohol (23). Similarly, tobacco consumption seems to cooperate with HPV infection to increase the risk of $\operatorname{HNSCC}(24,25)$. In fact, mice transgenic for the HPV16 E6 and E7 oncogenes showed increased susceptibility to oral carcinogenesis induced by the tobacco-related carcinogen 4-nitroquinoline-1-oxide (26).

The connection between HPV and certain HNSCC subtypes was first pointed out twenty years ago (6). This seminal study identified HPV in $25 \%$ of HNSCC samples and in $62 \%$ of those located in the tonsils and the tongue base, with HPV16 being most commonly found. HPV-positive tumours showed a more favourable biological behaviour compared to HPV-negative HNSCC. Over the years, these initial observations were reinforced by multiple reports from different groups and oral infection with high-risk HPV, especially HPV16, was consistently associated with increased HNSCC risk (27-29). Studies on bovine (30), canine (31), feline (32) and murine (33) models showed the ability of papillomaviruses to infect and induce different types of lesions in the oral cavity, as previously reviewed (34-36). More recently, our group demonstrated the ability of HPV16 to specifically induce tongue base HNSCC in transgenic mice (37), providing experimental evidence to support the etiologic role of HPV16 in this type of cancer. There are over $200 \mathrm{HPV}$ types, which are transmitted by direct contact and most often cause benign lesions (38). The host's immune system is generally able to clear HPV infections, leading to spontaneous regression of lesions within two years, as previously reviewed $(39,40)$. However, some HPV types, known as high-risk HPVs (e.g., HPV16, 18 and 31) show increased ability to establish persistent infections and induce lesions that may progress towards anogenital and oropharyngeal cancers (41-43). The carcinogenic activity of high-risk HPVs is largely attributed to their E6 and E7 oncoproteins with some less-understood contributions by the E5 oncoprotein $(44,45)$, as recently reviewed (46). The E6 and E7 oncoproteins interact with two tumour suppressor proteins, p53 and the retinobastoma protein (pRb), inducing their degradation and dysregulating key cellular functions such as proliferation, survival and DNA repair (46). High-risk HPVs also have mechanisms to promote the immune evasion of infected cells $(47,48)$ and are able to interfere with the epigenetic modulation of gene expression through microRNA networks, as previously reviewed (49).

Histologically, HPV-positive HNSCC tends to be less differentiated than HPV-negative tumours (50). Since the beginning of the XXI century, the incidence of HPV-positive HNSCC has been steadily increasing while that of HPVnegative HNSCC decreased a trend that is speculated to be caused by changing sexual habits (51). HPV-positive tumours tend to respond better to therapy (52-54) and specific therapeutic modalities, including de-escalation of aggressive chemo-radiation treatment, are currently under study $(11,55,56)$.

\section{Hormone Receptors in HNSCC}

The role of hormone receptors is well characterized in several types of cancers. This is particularly true in the case of sex hormone (estrogen, androgen, progesterone) receptors in malignancies like breast cancer $(15,57)$ and prostate cancer (16), where the expression of sex hormone receptors is critical to define tumour subtypes with distinguishing biopathological characteristics and different responses to therapy. The use of hormonal therapies for treating androgendependent prostate cancer (e.g., enzalutamide) and some types of breast cancer (e.g., tamoxifen) is well established (58-60). Androgen receptors (AR) were detected in the normal oral mucosa using immunohistochemistry on frozen samples (61). More recently, Fei et al. (2018) reported low levels of AR expression in only a minority of laryngeal samples (62). The same authors reported similar results 
concerning the expression of prolactin receptors in normal laryngeal mucosa. There are two types of oestrogen receptors commonly located in the cell nucleus, the well-known alpha and beta (ER $\alpha$ and $E R \beta)$, located in the cell nucleus (63) in contrast, the G-protein-coupled estrogen receptor (GPER) is associated with the cell membrane rather than the nucleus and triggers a number non-genomic effects (64). Although GPER has been implicated in some types of cancer (65), its role is not so well characterized as that of ER $\alpha$ and ER $\beta$. Initial studies performed in the 1980s showed conflicting results regarding the expression of ER or the progesterone receptor in the laryngeal mucosa $(66,67)$. In the early 2000 s, Valimaa et al. reported that normal oral mucosa and salivary glands express ER $\beta$ (68), but another study using paraffinembedded samples from a small patient cohort $(n=5)$ reported that the oral mucosa was negative for $E R \alpha$ and progesterone receptors (69). Lukits et al., using frozen and paraffin-embedded samples from 10 patients obtained different results. When analyzing frozen samples, both the oral mucosa and the glottis were positive for ER $\alpha, E R \beta$ and progesterone receptors on the mRNA level. Using immunofluorescence techniques, the authors observed expression of ER $\alpha$ on the oral and glottic mucosa while ER $\beta$ was more abundant in the glandular epithelium (70). These findings suggest that the methods for studying the expression of those markers in the oropharyngeal cavity need to be standardized, especially the use of frozen versus paraffinembedded material and the immunohistochemical techniques employed. Due to the complexity of the oropharyngeal and laryngeal cavities, it is also possible that specific anatomic areas (e.g., larynx versus tongue) express some hormone receptors while others do not.

The expression patterns of sex hormone receptors in HNSCC is also unclear, which is unsurprising considering these difficulties and the heterogeneity of these tumours. Androgen receptor was found to be expressed in salivary gland duct carcinomas and other non-squamous head and neck cancers, as recently reviewed (71). The present review will focus on data concerning HNSCC.

An initial study performed in 1984 using a dextran-coated charcoal method for determining oestrogen and progesterone receptors in HNSCC samples found ER in only 2 out of 75 samples and no progesterone receptors (66). Virolainen et al. (1986) detected AR, ER and PR in 31\%, 69\% and 35\% respectively of frozen laryngeal squamous cell carcinoma (SCC) samples, using hormone binding assays (72). In contrast, Ferguson et al. (1987) using immunohistochemistry on frozen samples reported that neither ER nor PR were expressed by laryngeal carcinomas (67). Twenty years later, Lukits et al. studied the expression of progesterone receptors (PR), and the two distinct estrogen receptors, $\mathrm{ER} \alpha$ and $\mathrm{ER} \beta$ in 67 frozen oral, laryngeal and hypopharyngeal SCC samples at the mRNA and protein levels (70). The authors observed that all three receptors were expressed by epithelial cells in these cancers and that $\mathrm{ER} \alpha$ was more frequently expressed than ER $\beta$. These two receptors were expressed in their wild-type form or as splice variants $\delta 3$ and $\delta 5$ for ER $\alpha$ and ER $\beta$, respectively. Most lesions expressed both ER and PR (41.8\% of lesions), rather than ER or PR alone (8.9\%). Almost 10 years later, another study compared the expression on the progesterone receptor (PR) and ER $\alpha$ in male and female patients and in normal oral mucosa, intraepithelial lesions and oral SCC, and only observed expression of $\mathrm{ER} \alpha$ in $11 \%$ of intraepithelial lesions and SCCs (69). In the same year, Grsic et al. (2016) studied the expression of ER $\beta$ in a larger cohort (174 patients, 165 of which were male). Interestingly, this study showed ER $\beta$ expression in $42 \%$ of patients (73). Most negative tumours were laryngeal primaries $(p=0.04)$, and the expression of ER $\beta$ was consistently higher in tumours from other sites (oral cavity, hypopharynx, oropharynx) without further anatomy-related differences. Another study found that $16 \%$ of oropharyngeal cancers expressed AR, 27\% expressed PR and $63 \%$ expressed $\mathrm{ER} \beta$, while ER $\alpha$ expression was not detected (74). In contrast, Kano et al. (2019) detected both ER $\alpha$ and ER $\beta$ in $29 \%$ and $36 \%$ of oropharyngeal cancer samples, respectively (75). Using immunohistochemistry on paraffin-embedded materials, Wu et al. (2014) reported that AR was expressed in two-thirds (14/21) specimens of oral squamous cell carcinoma (OSCC). AR knockdown using short hairpin RNA reduced the proliferation of representative cell lines in vitro and abolished their growth when xenografted in mice (76). More recently and in line with these findings, 10/23 OSCC patients were found to be positive for AR using paraffin-embedded material (77). The same authors reported that AR expression was significantly associated with increased phosphorylated epidermal growth factor receptor (EGFR). Using in vitro systems, AR pharmacological inhibition reduced EGFR phosphorylation while AR agonists had the opposite effect, suggesting AR promotes EGFR signalling in those tumours. Those in vitro observations also associated AR signalling with enhanced cell migration, potentially increasing tumour aggressiveness. Another recent study using a larger cohort (total $n=196$ ) of metastatic and non-metastatic OSCC patients suggested that AR cytoplasmic accumulation associates with moderately increased risk of metastasis (78). The significance of AR cytoplasmic immunostaining in this context requires additional clarification, especially considering that AR splice variants play an important role in prostate cancer and some of those variants may accumulate in the cytoplasm (Zhan et al., 2017) (79). Overall, although $\mathrm{AR}$ is expressed in a majority of HNSCC samples, its role in tumour biopathology and its implications for patient outcome remain largely obscure. Table I summarizes data on the expression of sex hormone receptors in HNSCC. 
Table I. Expression of sex hormone receptors in HNSCC.

\begin{tabular}{|c|c|c|c|c|}
\hline Hormone receptor & Positivity & Sample & Method & References \\
\hline \multirow[t]{5}{*}{ AR } & $8 / 21$ & Laryngeal SCC, frozen & HBA & Virolainen et al. (1986) \\
\hline & $31 / 199$ & OPSCC, FFPE & $\mathrm{IHC}$ & Mohamed et al. (2018) \\
\hline & $14 / 21$ & Oral SCC, FFPE & $\mathrm{IHC}$ & Wu et al. (2004) \\
\hline & $10 / 23$ & Oral SCC, FFPE & $\mathrm{IHC}$ & Liu et al. (2018) \\
\hline & Unreported & Oral SCC, FFPE & $\mathrm{IHC}$ & Tomasovic-Longaric et al. (2019) \\
\hline \multirow[t]{6}{*}{ PR } & None & Normal larynx, frozen & $\mathrm{IHC}$ & Ferguson et al. (1987) \\
\hline & None & Laryngeal SCC, frozen & $\mathrm{IHC}$ & Ferguson et al. (1987) \\
\hline & None & Oral SCC, FFPE & $\mathrm{IHC}$ & Grimm et al. (2016) \\
\hline & $21 / 43$ & Laryngeal and hypopharyngeal SCC, frozen & $\mathrm{IHC}$ & Lukits et al. (2007) \\
\hline & $8 / 15$ & Laryngeal SCC, frozen & HBA & Virolainen et al. 1986 \\
\hline & $54 / 199$ & OPSCC, FFPE & $\mathrm{IHC}$ & Mohamed et al. (2018) \\
\hline \multirow[t]{4}{*}{$\mathrm{ER} \alpha$} & $5 / 46$ & Oral SCC, FFPE & $\mathrm{IHC}$ & Grimm et al. (2016) \\
\hline & $16 / 43$ & Laryngeal and hypopharyngeal SCC, frozen & $\mathrm{IHC}$ & Lukits et al. (2007) \\
\hline & None & OPSCC, FFPE & $\mathrm{IHC}$ & Mohamed et al. (2018) \\
\hline & $19 / 68$ & OPSCC, FFPE & $\mathrm{IHC}$ & Kano et al. (2019) \\
\hline \multirow{4}{*}{$\mathrm{ER} \beta$} & $73 / 174$ & Larynx, oral cavity, hypopharynx, oropharynx SCC, FFPE & $\mathrm{IHC}$ & Grsic et al. (2016) \\
\hline & $11 / 43$ & Laryngeal and hypopharyngeal SCC, frozen & $\mathrm{IHC}$ & Lukits et al. (2007) \\
\hline & $126 / 199$ & OPSCC, FFPE & $\mathrm{IHC}$ & Mohamed et al. (2018) \\
\hline & $23 / 64$ & OPSCC, FFPE & $\mathrm{IHC}$ & Kano et al. (2019) \\
\hline
\end{tabular}

IHC: Immunohistochemistry, FFPE: formalin-fixed paraffin embedded, HBA: hormone binding assays, SCC: squamous cell carcinoma, OPSCC: oropharyngeal squamous cell carcinoma, FFPE: formalin-fixed paraffin-embedded.

\section{HPV and Hormonal Receptors}

Mohamed et al. (2018) observed a correlation between HPVpositive tumours with increased expression of AR and reduced expression of PR ( $p<0.001$ for both markers). Kano et al. (2019) reported that $\mathrm{ER} \alpha$ expression is associated with HPV-positive oropharyngeal cancers ( $p=0.018$ versus HPVnegative) and suggest that ER $\alpha$ facilitates the integration of HPV DNA into the host's genome by promoting DNA hypermutation through the apolipoprotein B mRNA-editing catalytic polypeptide 3 (APOBEC3). In fact, HPV-positive HNSCC has a specific mutational landscape associated with APOBEC, as previously described (80). In the cervical transformation zone, estrogen exposure promotes neoplastic transformation and the development of cervical cancer induced by HPV16 $(17,18)$. In $35 \%$ of cervical cancers, expression of aromatase, the rate-limiting enzyme involved oestrogen synthesis, is up-regulated compared to normal cervical mucosa and to precancerous lesions (81). Aromatase expression was associated with increased expression of ER $\alpha / E R \beta$ and reduced PR expression, as well as with upregulation of HPV oncogenes E6 and E7 and increased cell proliferation.
Overall, it is possible that estrogen signaling via $\mathrm{ER} \alpha$ and/or ER $\beta$ plays a significant role in HPV-positive HNSCC, namely by promoting viral integration into the host cell's genome, as observed in cervical cancer (Figure 1). Additional evidence is needed to define the possible role of other hormone receptors such as AR and PR.

\section{Therapeutic and Prognostic Relevance of Hormone Receptors in HNSCC}

The clinical significance of sex hormone receptors in HNSCC has been addressed by multiple recent studies and pre-clinical studies of hormonal therapy have been attempted with limited success. As mentioned in the previous section, AR expression is associated with HPV infection in HNSCC (74). Interestingly, AR up-regulation was correlated with reduced survival $(p<0.005)$ in HNSCC patients and was found to be driven by microRNA-21 (82). Concerning female sex hormone receptors, Lukits et al. (2007) did not find any significant associations between the expression of PR, ER $\alpha$ or ER $\beta$ and patient prognosis. However, PR expression was associated with reduced disease-specific survival $(p=0.001)$ by a recent study (74). Egloff et al. (2009) suggested the 


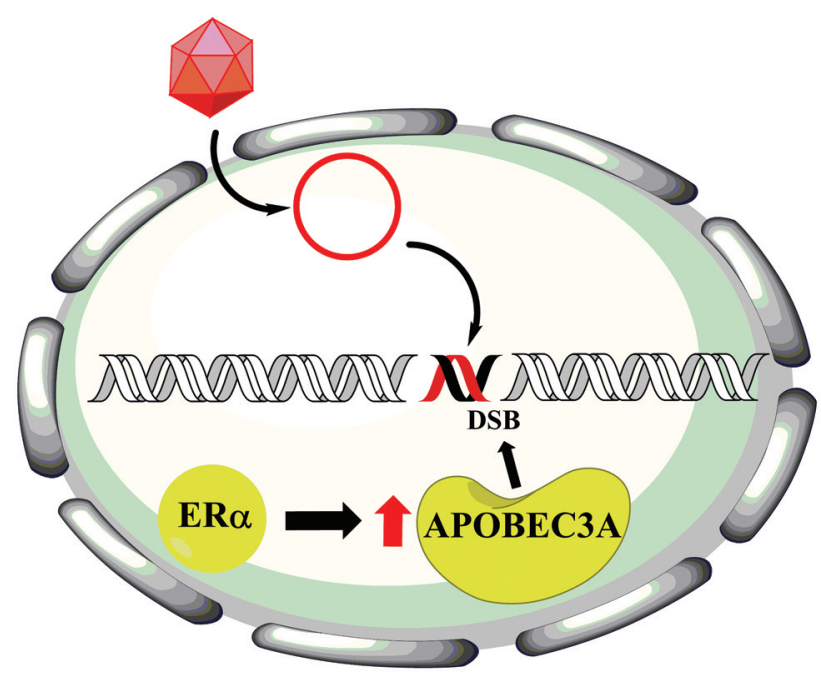

Figure 1. A possible association between ERQ and HPV-positive HNSCC, as proposed by Kano et al (75). Estrogen receptor alpha (ERa) up-regulates the apolipoprotein B mRNA-editing catalytic polypeptide 3 (APOBEC3), inducing DNA double-strand breaks which facilitate the integration of HPV DNA into the host cell genome.

existence of a cross-talk between ER $\alpha$ and the epidermal growth factor receptor (EGFR) in HNSCC and showed that the simultaneous expression of both receptors significantly reduced progression-free survival compared with tumours with only one of those receptors (hazard ratio 4.09, $p=0.01$ ). Interestingly, this was not observed for ER $\beta$. In line with these observations, the authors also showed that a combined in vitro treatment of HNSCC cells with estradiol and EGF significantly increased cell invasion, compared with treatments with each single ligand (83). Lin et al. (2011) also reported that ER $\alpha$ cooperates with EGFR to promote chemoresistance of HNSCC cell lines in vitro (84). The authors reported that $\mathrm{ER} \alpha$ up-regulates the anti-apoptotic protein B cell lymphoma 2 (Bcl-2) and rescues EGFR levels, promoting survival and proliferation (Figure 2). Early in vivo trials of anti-oestrogen therapies against cervical cancer in HPV-transgenic mouse models $(85,86)$ showed positive results. Trials of tamoxifen against HNSCC (87) allowed researchers to overcome cisplatin resistance in vitro. However, the mechanism of action of tamoxifen in ER-negative HNSCC cell lines remains unclear (88). If a rationale for hormonal therapy in HNSCC is to be found the role of hormonal receptors in this type of cancer needs to be clarified.

Interestingly, ER $\alpha$ was associated with improved overall survival in patients with HPV-positive oropharyngeal cancer $(p=0.029)$ (75), possibly because the APOBEC mutational signature of these tumors makes them more immunogenic. More recently, Grsic et al. (2016) reported that ER $\beta$ expression in oropharyngeal cancer correlated with improved 5 years survival

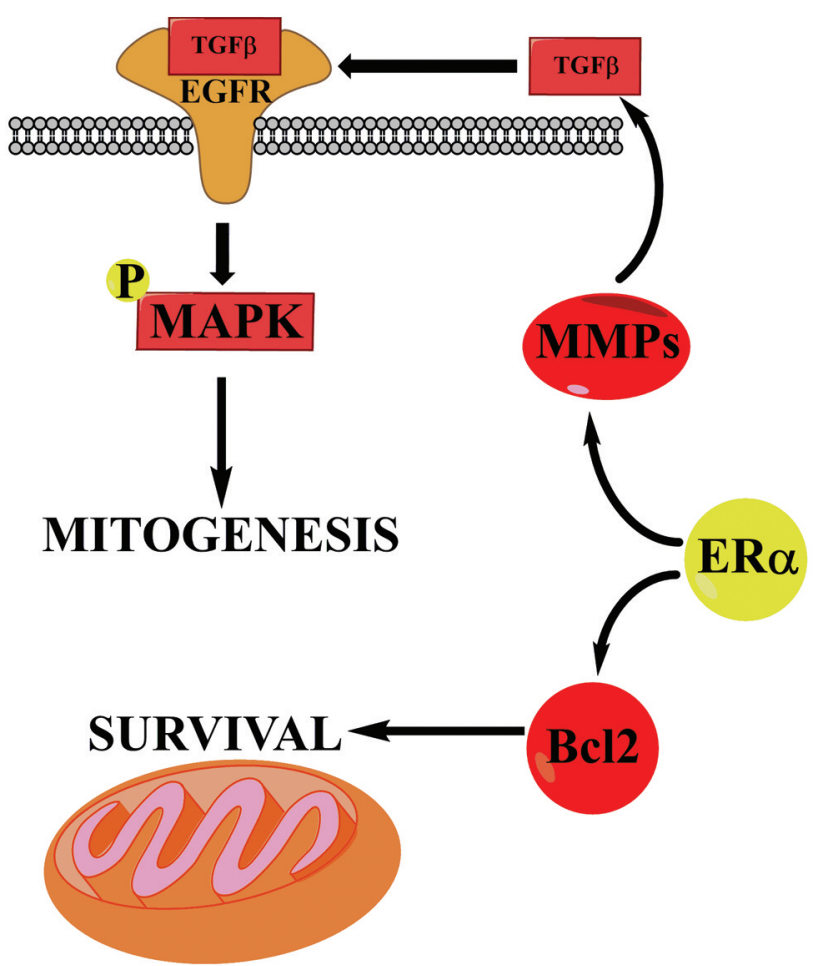

Figure 2. Estrogen receptor alpha (ER ) was proposed to activate multiple signaling pathways leading to cell survival and proliferation. Up-regulation of B-cell lymphoma 2 (Bcl2) blocks the mitochondrial apoptotic pathway. The release of ligands for the epithelial growth factor receptor (EGFR) via matrix metalloproteinases leads to phosphorylation of mitogen-activated protein kinase (MAPK) and drives cell proliferation.

(35\% versus $25 \%$ in patients with ER $\beta$-negative cancers, $p=0.045)$. The same was not observed in other anatomic sites. The HPV status of these tumours was not reported and may have been a confounding variable in this study. Grunow et al. (2017) made additional and more complex observations on the role of ER $\beta$. Radiotherapy-treated oropharyngeal cancers expressing ER $\beta$ showed higher progression-free survival $(p=0.002)$ and disease-specific survival $(p=0.01)$, compared with negative cases. However, the authors also observed that ER $\beta$ up-regulated the submaxillary gland androgen-regulated protein 3A (SMR3A) and promoted the resistance to radiation therapy in vitro (89). Tumours expressing both ER $\beta$ and SMR3A had poor prognosis, similar to the ER $\beta$-negative subgroup. These observations suggest that ER $\beta$ activates multiple pathways in HNSCC and may either play a protective role or, on the contrary, promote radio-resistance. The membrane associated GPER has also been implicated in laryngeal cancer, even if only by an in vitro study (90). GPER was shown to up-regulate interleukin-6 expression in response to bisphenol A in vitro, increasing cell proliferation and invasion. 
Overall, sex hormone receptors seem to influence the biopathology of HNSCC mainly by promoting DNA hypermutation and facilitating HPV integration or by cooperating with EGFR in the case of ER $\alpha$. The role of ER $\beta$ seems to be more complex and requires additional investigation. The expression of sex hormone receptors may be of prognostic value, if studied in the right tumour subgroups. The use of these receptors as therapeutic targets is still not in close sight. However, it is tempting to speculate that HNSCC subgroups may benefit from combination therapies of hormone receptor modulators with anti-EGFR drugs (e.g., erlotinib).

\section{Conflicts of Interest}

The Authors declare that they have no conflicts of interest.

\section{Authors' Contributions}

CP Oliveira Neto: article research, manuscript writing and submission; HO Brito: manuscript editing and review; RMG da Costa: article research, manuscript writing and drawing figures; LMO Brito: manuscript review.

\section{Acknowledgements}

This work was supported by the Fundação de Amparo à Pesquisa do Estado do Maranhão - FAPEMA (grant number 01285/17).

\section{References}

1 Lydiatt WM, Patel SG, O'Sullivan B, Brandwein MS, Ridge JA, Migliacci JC, Loomis AM and Shah JP: Head and neck cancersmajor changes in the American Joint Committee on cancer eighth edition cancer staging manual. CA Cancer J Clin 67(2): 122-137, 2017. PMID: 28128848. DOI: 10.3322/caac.21389

2 Bray F, Ferlay J, Soerjomataram I, Siegel RL, Torre LA and Jemal A: Global cancer statistics 2018: GLOBOCAN estimates of incidence and mortality worldwide for 36 cancers in 185 countries. CA Cancer J Clin 68(6): 394-424, 2018. PMID: 30207593. DOI: $10.3322 /$ caac. 21492

3 Siegel RL, Miller KD and Jemal A: Cancer statistics, 2019. CA Cancer J Clin 69(1): 7-34, 2019. PMID: 30620402. DOI: $10.3322 /$ caac. 21551

4 Wyss A, Hashibe M, Chuang SC, Lee YC, Zhang ZF, Yu GP, Winn DM, Wei Q, Talamini R, Szeszenia-Dabrowska N, Sturgis EM, Smith E, Shangina O, Schwartz SM, Schantz S, Rudnai P, Purdue MP, Eluf-Neto J, Muscat J, Morgenstern H, Michaluart P Jr, Menezes A, Matos E, Mates IN, Lissowska J, Levi F, Lazarus P, La Vecchia C, Koifman S, Herrero R, Hayes RB, Franceschi S, Wünsch-Filho V, Fernandez L, Fabianova E, Daudt AW, Dal Maso L, Curado MP, Chen C, Castellsague X, de Carvalho MB, Cadoni G, Boccia S, Brennan P, Boffetta P and Olshan AF: Cigarette, cigar, and pipe smoking and the risk of head and neck cancers: pooled analysis in the International Head and Neck Cancer Epidemiology Consortium. Am J Epidemiol 178(5): 679690, 2013. PMID: 23817919. DOI: 10.1093/aje/kwt029
5 Hashibe M, Brennan P, Benhamou S, Castellsague X, Chen C, Curado MP, Dal Maso L, Daudt AW, Fabianova E, Fernandez L, Wünsch-Filho V, Franceschi S, Hayes RB, Herrero R, Koifman S, La Vecchia C, Lazarus P, Levi F, Mates D, Matos E, Menezes A, Muscat J, Eluf-Neto J, Olshan AF, Rudnai P, Schwartz SM, Smith E, Sturgis EM, Szeszenia-Dabrowska N, Talamini R, Wei Q, Winn DM, Zaridze D, Zatonski W, Zhang ZF, Berthiller J and Boffetta P: Alcohol drinking in never users of tobacco, cigarette smoking in never drinkers, and the risk of head and neck cancer: pooled analysis in the International Head and Neck Cancer Epidemiology Consortium. J Natl Cancer Inst 99(10): 777-789, 2007. PMID: 17505073. DOI: 10.1093/jnci/djk 179

6 Gillison ML, Koch WM, Capone RB, Spafford M, Westra WH, Wu L, Zahurak ML, Daniel RW, Viglione M, Symer DE, Shah KV and Sidransky D: Evidence for a causal association between human papillomavirus and a subset of head and neck cancers. J Natl Cancer Inst 92(9): 709-720, 2000. PMID: 10793107. DOI: 10.1093/jnci/92.9.709

7 Ramqvist T, Grün N and Dalianis T: Human papillomavirus and tonsillar and base of tongue cancer. Viruses 7(3): 1332-1343, 2015. PMID: 25803099. DOI: 10.3390/v7031332

8 Cohen N, Fedewa S and Chen AY: Epidemiology and Demographics of the Head and Neck Cancer Population. Oral Maxillofac Surg Clin North Am 30(4): 381-395, 2018. PMID: 30078696. DOI: $10.1016 /$ j.coms.2018.06.001

9 Cardin GB, Bernard M, Bahig H, Nguyen-Tan PF, Ballivy O, Filion E, Soulieres D, Philouze P, Ayad T, Guertin L, Bissada E, Rodier F and Christopoulos A: Single Nucleotide Polymorphism rs6942067 is a risk factor in young and in non-smoking patients with HPV negative head and neck squamous cell carcinoma. Cancers (Basel) 12(1): 55, 2019. PMID: 31878157. DOI: 10.3390/cancers 12010055

10 Liu C, Sadat SH, Ebisumoto K, Sakai A, Panuganti BA, Ren S, Goto Y, Haft S, Fukusumi T, Ando M, Saito Y, Guo T, Tamayo P, Yeerna H, Kim W, Hubbard J, Sharabi AB, Gutkind JS and Califano JA: Cannabinoids promote progression of HPV-positive head and neck squamous cell carcinoma via p38 MAPK activation. Clin Cancer Res 26(11): 2693-2703, 2020. PMID: 31932491. DOI: 10.1158/1078-0432.CCR-18-3301

11 Howlader N, Noone AM, Krapcho M, Miller D, Bishop K and Altekruse SF: SEER cancer statistics review, 1975-2014. Natl Cancer Inst pp. 1-12, 2017. Available at: https://seer.cancer.gov/ archive/csr/1975_2014/ [Last accessed on June 24, 2021]

12 de Martel C, Plummer M, Vignat J and Franceschi S: Worldwide burden of cancer attributable to HPV by site, country and HPV type. Int J Cancer 141(4): 664-670, 2017. PMID: 28369882. DOI: $10.1002 /$ ijc.30716

13 Leemans CR, Snijders PJF and Brakenhoff RH: The molecular landscape of head and neck cancer. Nat Rev Cancer 18(5): 269282, 2018. PMID: 29497144. DOI: 10.1038/nrc.2018.11

14 de la Iglesia JV, Slebos RJC, Martin-Gomez L, Wang X, Teer JK, Tan AC, Gerke TA, Aden-Buie G, van Veen T, Masannat J, Chaudhary R, Song F, Fournier M, Siegel EM, Schabath MB, Wadsworth JT, Caudell J, Harrison L, Wenig BM, Conejo-Garcia J, Hernandez-Prera JC and Chung $\mathrm{CH}$ : Effects of tobacco smoking on the tumor immune microenvironment in head and neck squamous cell carcinoma. Clin Cancer Res 26(6): 14741485, 2020. PMID: 31848186. DOI: 10.1158/1078-0432.CCR19-1769 
15 Harbeck N, Penault-Llorca F, Cortes J, Gnant M, Houssami N, Poortmans P, Ruddy K, Tsang J and Cardoso F: Breast cancer. Nat Rev Dis Primers 5(1): 66, 2019. PMID: 31548545. DOI: 10.1038/s41572-019-0111-2

16 Labrecque MP, Coleman IM, Brown LG, True LD, Kollath L, Lakely B, Nguyen HM, Yang YC, da Costa RMG, Kaipainen A, Coleman R, Higano CS, Yu EY, Cheng HH, Mostaghel EA, Montgomery B, Schweizer MT, Hsieh AC, Lin DW, Corey E, Nelson PS and Morrissey C: Molecular profiling stratifies diverse phenotypes of treatment-refractory metastatic castrationresistant prostate cancer. J Clin Invest 129(10): 4492-4505, 2019. PMID: 31361600. DOI: 10.1172/JCI128212

17 Arbeit JM, Howley PM and Hanahan D: Chronic estrogeninduced cervical and vaginal squamous carcinogenesis in human papillomavirus type 16 transgenic mice. Proc Natl Acad Sci USA 93(7): 2930-2935, 1996. PMID: 8610145. DOI: 10.1073/pnas.93.7.2930

18 Brake T and Lambert PF: Estrogen contributes to the onset, persistence, and malignant progression of cervical cancer in a human papillomavirus-transgenic mouse model. Proc Natl Acad Sci USA 102(7): 2490-2495, 2005. PMID: 15699322. DOI: 10.1073/pnas.0409883102

19 Berthiller J, Straif K, Agudo A, Ahrens W, Bezerra Dos Santos A, Boccia S, Cadoni G, Canova C, Castellsague X, Chen C, Conway D, Curado MP, Dal Maso L, Daudt AW, Fabianova E, Fernandez L, Franceschi S, Fukuyama EE, Hayes RB, Healy C, Herrero R, Holcatova I, Kelsey K, Kjaerheim K, Koifman S, Lagiou P, La Vecchia C, Lazarus P, Levi F, Lissowska J, Macfarlane T, Mates D, McClean M, Menezes A, Merletti F, Morgenstern H, Muscat J, Olshan AF, Purdue M, Ramroth H, Rudnai P, Schwartz SM, Serraino D, Shangina O, Smith E, Sturgis EM, SzeszeniaDabrowska N, Thomson P, Vaughan TL, Vilensky M, Wei Q, Winn DM, Wünsch-Filho V, Zhang ZF, Znaor A, Ferro G, Brennan P, Boffetta P, Hashibe M and Lee YC: Low frequency of cigarette smoking and the risk of head and neck cancer in the INHANCE consortium pooled analysis. Int J Epidemiol 45(3): 835-845, 2016. PMID: 26228584. DOI: $10.1093 / \mathrm{ije} / \mathrm{dyv} 146$

20 Goldstein BY, Chang SC, Hashibe M, La Vecchia C and Zhang ZF: Alcohol consumption and cancers of the oral cavity and pharynx from 1988 to 2009: an update. Eur J Cancer Prev 19(6): 431-465, 2010. PMID: 20679896. DOI: 10.1097/CEJ.0b013e32833d936d

21 Boeing $\mathrm{H}$ and EPIC Working Group on Dietary Patterns.: Alcohol and risk of cancer of the upper gastrointestinal tract: first analysis of the EPIC data. IARC Sci Publ 156: 151-154, 2002. PMID: 12484152.

22 Alcohol drinking. IARC Working Group, Lyon, 13-20 October 1987. IARC Monogr Eval Carcinog Risks Hum 44: 1-378, 1988 PMID: 3236394.

23 Koch WM and McQuone S: Clinical and molecular aspects of squamous cell carcinoma of the head and neck in the nonsmoker and nondrinker. Curr Opin Oncol 9(3): 257-261, 1997. PMID: 9229148. DOI: 10.1097/00001622-199709030-00007

24 Chaturvedi AK, D'Souza G, Gillison ML and Katki HA: Burden of HPV-positive oropharynx cancers among ever and never smokers in the U.S. population. Oral Oncol 60: 61-67, 2016. PMID: 27531874. DOI: 10.1016/j.oraloncology.2016.06.006

25 Liu L, Wu G, Xue F, Li Y, Shi J, Han J, Zhang X, Na Y, Zhang $\mathrm{H}$, Tang $\mathrm{X}, \mathrm{Pu} \mathrm{H}$, Yuan $\mathrm{Q}$, Zhang L and Yang M: Functional CYP1A1 genetic variants, alone and in combination with smoking, contribute to development of head and neck cancers.
Eur J Cancer 49(9): 2143-2151, 2013. PMID: 23462525. DOI: 10.1016/j.ejca.2013.01.028

26 Jabbar S, Strati K, Shin MK, Pitot HC and Lambert PF: Human papillomavirus type 16 E6 and E7 oncoproteins act synergistically to cause head and neck cancer in mice. Virology 407(1): 60-67, 2010. PMID: 20797753. DOI: 10.1016/j.virol. 2010.08 .003

27 D'Souza G, Kreimer AR, Viscidi R, Pawlita M, Fakhry C, Koch WM, Westra WH and Gillison ML: Case-control study of human papillomavirus and oropharyngeal cancer. N Engl J Med 356(19): 1944-1956, 2007. PMID: 17494927. DOI: 10.1056/ NEJMoa065497

28 Herrero R, Castellsagué X, Pawlita M, Lissowska J, Kee F, Balaram P, Rajkumar T, Sridhar H, Rose B, Pintos J, Fernández L, Idris A, Sánchez MJ, Nieto A, Talamini R, Tavani A, Bosch FX, Reidel U, Snijders PJ, Meijer CJ, Viscidi R, Muñoz N, Franceschi $\mathrm{S}$ and IARC Multicenter Oral Cancer Study Group: Human papillomavirus and oral cancer: the International Agency for Research on Cancer multicenter study. J Natl Cancer Inst 95(23): 1772-1783, 2003. PMID: 14652239. DOI: 10.1093/jnci/djg 107

29 Smith EM, Ritchie JM, Summersgill KF, Hoffman HT, Wang DH, Haugen TH and Turek LP: Human papillomavirus in oral exfoliated cells and risk of head and neck cancer. J Natl Cancer Inst 96(6): 449-455, 2004. PMID: 15026470. DOI: 10.1093/jnci/djh074

30 Zhu W, Dong J, Shimizu E, Hatama S, Kadota K, Goto Y and Haga T: Characterization of novel bovine papillomavirus type 12 (BPV-12) causing epithelial papilloma. Arch Virol 157(1): 85-91, 2012. PMID: 22033594. DOI: 10.1007/s00705-011-1140-7

31 Munday JS, Dunowska M, Laurie RE and Hills S: Genomic characterisation of canine papillomavirus type 17, a possible rare cause of canine oral squamous cell carcinoma. Vet Microbiol 182: 135-140, 2016. PMID: 26711040. DOI: 10.1016/j.vetmic.2015. 11.015

32 Chu S, Wylie TN, Wylie KM, Johnson GC, Skidmore ZL, Fleer $\mathrm{M}$, Griffith OL and Bryan JN: A virome sequencing approach to feline oral squamous cell carcinoma to evaluate viral causative factors. Vet Microbiol 240: 108491, 2020. PMID: 31902496. DOI: $10.1016 /$ j.vetmic.2019.108491

33 Cladel NM, Budgeon LR, Balogh KK, Cooper TK, Brendle SA, Christensen ND, Schell TD and Hu J: Mouse papillomavirus infection persists in mucosal tissues of an immunocompetent mouse strain and progresses to cancer. Sci Rep 7(1): 16932, 2017. PMID: 29208932. DOI: 10.1038/s41598-017-17089-4

34 Gil da Costa RM, Peleteiro MC, Pires MA and DiMaio D: An update on canine, feline and bovine papillomaviruses. Transbound Emerg Dis 64(5): 1371-1379, 2017. PMID: 27615361. DOI: $10.1111 /$ tbed.12555

35 Gil da costa R and Medeiros R: Bovine papillomavirus: opening new trends for comparative pathology. Archives of Virology 159(2): 191-198, 2019. DOI: 10.1007/s00705-013-1801-9

36 Santos C, Vilanova M, Medeiros R and Gil da Costa RM: HPVtransgenic mouse models: Tools for studying the cancerassociated immune response. Virus Res 235: 49-57, 2017. PMID: 28385491. DOI: 10.1016/j.virusres.2017.04.001

37 Mestre VF, Medeiros-Fonseca B, Estêvão D, Casaca F, Silva S, Félix A, Silva F, Colaço B, Seixas F, Bastos MM, Lopes C, Medeiros R, Oliveira PA and Gil da Costa RM: HPV16 is sufficient to induce squamous cell carcinoma specifically in the tongue base in transgenic mice. J Pathol 251(1): 4-11, 2020. PMID: 31994197. DOI: 10.1002/path.5387 
38 Burd EM: Human papillomavirus and cervical cancer. Clin Microbiol Rev 16(1): 1-17, 2003. PMID: 12525422. DOI: 10.1128/CMR.16.1.1-17.2003

39 Moscicki AB, Shiboski S, Broering J, Powell K, Clayton L, Jay N, Darragh TM, Brescia R, Kanowitz S, Miller SB, Stone J, Hanson E and Palefsky J: The natural history of human papillomavirus infection as measured by repeated DNA testing in adolescent and young women. J Pediatr 132(2): 277-284, 1998. PMID: 9506641. DOI: 10.1016/s00223476(98)70445-7

40 Egawa N, Egawa K, Griffin H and Doorbar J: Human papillomaviruses; epithelial tropisms, and the development of neoplasia. Viruses 7(7): 3863-3890, 2015. PMID: 26193301. DOI: $10.3390 / \mathrm{v} 7072802$

41 IARC Working Group on the Evaluation of Carcinogenic Risks to Humans: Human papillomaviruses. IARC Monogr Eval Carcinog Risks Hum 90: 1-636, 2007. PMID: 18354839

42 de Villiers EM: Cross-roads in the classification of papillomaviruses. Virology 445(1-2): 2-10, 2013. PMID: 23683837. DOI: 10.1016/j.virol.2013.04.023

43 Bzhalava D, Eklund $\mathrm{C}$ and Dillner $\mathrm{J}$ : International standardization and classification of human papillomavirus types. Virology 476: 341-344, 2015. PMID: 25577151. DOI: 10.1016/j.virol.2014.12.028

44 Gupta S, Kumar P and Das BC: HPV: Molecular pathways and targets. Curr Probl Cancer 42(2): 161-174, 2018. PMID: 29706467. DOI: $10.1016 /$ j.currproblcancer.2018.03.003

45 Ilahi NE and Bhatti A: Impact of HPV E5 on viral life cycle via EGFR signaling. Microb Pathog 139: 103923, 2020. PMID: 31836496. DOI: $10.1016 /$ j.micpath.2019.103923

46 Estêvão D, Costa NR, Gil da Costa RM and Medeiros R: Hallmarks of HPV carcinogenesis: The role of E6, E7 and E5 oncoproteins in cellular malignancy. Biochim Biophys Acta Gene Regul Mech 1862(2): 153-162, 2019. PMID: 30707946. DOI: $10.1016 /$ j.bbagrm.2019.01.001

47 Steinbach A and Riemer AB: Immune evasion mechanisms of human papillomavirus: An update. Int J Cancer 142(2): 224-229, 2018. PMID: 28865151. DOI: 10.1002/ijc.31027

48 Kwon MJ, Rho YS, Nam ES, Cho SJ, Park HR, Min SK, Seo J, Choe JY, Kim ES, Park B, Hong M and Min KW: Clinical implication of programmed cell death-1 ligand-1 expression in tonsillar squamous cell carcinoma in association with intratumoral heterogeneity, human papillomavirus, and epithelial-to-mesenchymal transition. Hum Pathol 80: 28-39, 2018. PMID: 29634978. DOI: 10.1016/j.humpath.2018.03.025

49 Santos JMO, Peixoto da Silva S, Costa NR, Gil da Costa RM and Medeiros R: The Role of MicroRNAs in the Metastatic Process of High-Risk HPV-Induced Cancers. Cancers (Basel) 10(12): 493, 2018. PMID: 30563114. DOI: 10.3390/cancers 10120493

50 El-Mofty SK: Human papillomavirus-related head and neck squamous cell carcinoma variants. Semin Diagn Pathol 32(1): 23 31, 2015. PMID: 25804342. DOI: 10.1053/j.semdp.2015.02.022

51 Herbenick D, Reece M, Schick V, Sanders SA, Dodge B and Fortenberry JD: Sexual behavior in the United States: results from a national probability sample of men and women ages 1494. J Sex Med 7 Suppl 5: 255-265, 2010. PMID: 21029383. DOI: $10.1111 / \mathrm{j} .1743-6109.2010 .02012 . x$

52 Gleber-Netto FO, Rao X, Guo T, Xi Y, Gao M, Shen L, Erikson K, Kalu NN, Ren S, Xu G, Fisch KM, Akagi K, Seiwert T, Gillison M, Frederick MJ, Johnson FM, Wang J, Myers JN,
Califano J, Skinner HD and Pickering CR: Variations in HPV function are associated with survival in squamous cell carcinoma. JCI Insight 4(1): e124762, 2019. PMID: 30626753. DOI: $10.1172 /$ jci.insight.124762

53 Mehanna H, Robinson M, Hartley A, Kong A, Foran B, FultonLieuw T, Dalby M, Mistry P, Sen M, O’Toole L, Al Booz H, Dyker K, Moleron R, Whitaker S, Brennan S, Cook A, Griffin M, Aynsley E, Rolles M, De Winton E, Chan A, Srinivasan D, Nixon I, Grumett J, Leemans CR, Buter J, Henderson J, Harrington K, McConkey C, Gray A, Dunn J and DeESCALaTE HPV Trial Group.: Radiotherapy plus cisplatin or cetuximab in low-risk human papillomavirus-positive oropharyngeal cancer (De-ESCALaTE HPV): an open-label randomised controlled phase 3 trial. Lancet 393(10166): 51-60, 2019. PMID: 30449623. DOI: 10.1016/S0140-6736(18)32752-1

54 Koneva LA, Zhang Y, Virani S, Hall PB, McHugh JB, Chepeha DB, Wolf GT, Carey TE, Rozek LS and Sartor MA: HPV integration in HNSCC correlates with survival outcomes, immune response signatures, and candidate drivers. Mol Cancer Res 16(1): 90-102, 2018. PMID: 28928286. DOI: 10.1158/1541-7786.MCR-17-0153

55 Lee JW, Parameswaran J, Sandoval-Schaefer T, Eoh KJ, Yang DH, Zhu F, Mehra R, Sharma R, Gaffney SG, Perry EB, Townsend JP, Serebriiskii IG, Golemis EA, Issaeva N, Yarbrough WG, Koo JS and Burtness B: Combined aurora kinase A (AURKA) and WEE1 inhibition demonstrates synergistic antitumor effect in squamous cell carcinoma of the head and neck. Clin Cancer Res 25(11): 3430-3442, 2019. PMID: 30755439. DOI: 10.1158/1078-0432.CCR-18-0440

56 Chera BS, Amdur RJ, Green R, Shen C, Gupta G, Tan X, Knowles M, Fried D, Hayes N, Weiss J, Grilley-Olson J, Patel S, Zanation A, Hackman T, Zevallos J, Blumberg J, Patel S, Kasibhatla M, Sheets N, Weissler M, Yarbrough W and Mendenhall W: Phase II trial of de-intensified chemoradiotherapy for human papillomavirus-associated oropharyngeal squamous cell carcinoma. J Clin Oncol 37(29): 2661-2669, 2019. PMID: 31411949. DOI: $10.1200 / J C O .19 .01007$

57 Alvarado A, Gil da Costa RM, Faustino-Rocha AI, Ferreira R, Lopes C, Oliveira PA and Colaço B: Effects of exercise training on breast cancer metastasis in a rat model. Int J Exp Pathol 98(1): 40-46, 2017. PMID: 28556395. DOI: 10.1111/iep.12225

58 Nyquist MD, Corella A, Mohamad O, Coleman I, Kaipainen A, Kuppers DA, Lucas JM, Paddison PJ, Plymate SR, Nelson PS and Mostaghel EA: Molecular determinants of response to high-dose androgen therapy in prostate cancer. JCI Insight 4(19): e129715, 2019. PMID: 31503550. DOI: 10.1172 /jci.insight.129715

59 Gao S, Ye H, Gerrin S, Wang H, Sharma A, Chen S, Patnaik A, Sowalsky AG, Voznesensky O, Han W, Yu Z, Mostaghel EA, Nelson PS, Taplin ME, Balk SP and Cai C: ErbB2 signaling increases androgen receptor expression in abiraterone-resistant prostate cancer. Clin Cancer Res 22(14): 3672-3682, 2016. PMID: 26936914. DOI: 10.1158/1078-0432.CCR-15-2309

60 Howell A, Cuzick J, Baum M, Buzdar A, Dowsett M, Forbes JF, Hoctin-Boes G, Houghton J, Locker GY, Tobias JS and ATAC Trialists' Group.: Results of the ATAC (Arimidex, Tamoxifen, Alone or in Combination) trial after completion of 5 years' adjuvant treatment for breast cancer. Lancet 365(9453): 60-62, 2005. PMID: 15639680. DOI: 10.1016/S0140-6736(04)17666-6 61 Ojanotko-Harri A, Forssell H, Laine M, Hurttia H, Bläuer M and Tuohimaa P: Immunohistochemical detection of androgen 
receptors in human oral mucosa. Arch Oral Biol 37(6): 511-514, 1992. PMID: 1637265. DOI: 10.1016/0003-9969(92)90108-k

62 Fei M, Zhang J, Zhou J, Xu Y and Wang J: Sex-related hormone receptor in laryngeal squamous cell carcinoma: correlation with androgen estrogen- $\alpha$ and prolactin receptor expression and influence of prognosis. Acta Otolaryngol 138(1): 66-72, 2018 PMID: 28889782. DOI: 10.1080/00016489.2017.1373851

63 Hewitt SC and Korach KS: Estrogen receptors: New directions in the new millennium. Endocr Rev 39(5): 664-675, 2018. PMID: 29901737. DOI: 10.1210/er.2018-00087

64 Revankar CM, Cimino DF, Sklar LA, Arterburn JB and Prossnitz ER: A transmembrane intracellular estrogen receptor mediates rapid cell signaling. Science 307(5715): 1625-1630, 2005. PMID: 15705806. DOI: 10.1126/science.1106943

65 Zhou X, Wang S, Wang Z, Feng X, Liu P, Lv XB, Li F, Yu FX, Sun Y, Yuan H, Zhu H, Xiong Y, Lei QY and Guan KL: Estrogen regulates Hippo signaling via GPER in breast cancer. J Clin Invest 125(5): 2123-2135, 2015. PMID: 25893606. DOI: 10.1172/JCI79573

66 Schuller DE, Abou-Issa H and Parrish R: Estrogen and progesterone receptors in head and neck cancer. Arch Otolaryngol 110(11): 725-727, 1984. PMID: 6091598. DOI: 10.1001/archotol.1984.00800370027006

67 Ferguson BJ, Hudson WR and McCarty KS Jr: Sex steroid receptor distribution in the human larynx and laryngeal carcinoma. Arch Otolaryngol Head Neck Surg 113(12): 1311-1315, 1987. PMID: 3314913. DOI: 10.1001/archotol.1987.01860120057008

68 Välimaa H, Savolainen S, Soukka T, Silvoniemi P, Mäkelä S, Kujari H, Gustafsson JA and Laine M: Estrogen receptor-beta is the predominant estrogen receptor subtype in human oral epithelium and salivary glands. J Endocrinol 180(1): 55-62, 2004. PMID: 14709144. DOI: 10.1677/joe.0.1800055

69 Grimm M, Biegner T, Teriete P, Hoefert S, Krimmel M, Munz $\mathrm{A}$ and Reinert S: Estrogen and progesterone hormone receptor expression in oral cavity cancer. Med Oral Patol Oral Cir Bucal 21(5): e554-e558, 2016. PMID: 27475696. DOI: $10.4317 /$ medoral. 21182

70 Lukits J, Remenár E, Rásó E, Ladányi A, Kásler M and Tímár $\mathrm{J}$ : Molecular identification, expression and prognostic role of estrogen- and progesterone receptors in head and neck cancer. Int J Oncol 30(1): 155-160, 2007. PMID: 17143524. DOI: 10.3892/ijo.30.1.155

71 Yeoh CC, Dabab N, Rigby E, Chhikara R, Akaev I, Gomez RS, Fonseca F, Brennan PA and Rahimi S: Androgen receptor in salivary gland carcinoma: A review of an old marker as a possible new target. J Oral Pathol Med 47(7): 691-695, 2018. PMID: 29863801. DOI: 10.1111/jop.12741

72 Virolainen E, Tuohimaa P, Aitasalo K, Kyttä J and VanharantaHiltunen R: Steroid hormone receptors in laryngeal carcinoma. Otolaryngol Head Neck Surg 94(4): 512-517, 1986. PMID: 3086815. DOI: 10.1177/019459988609400419

73 Grsic K, Opacic IL, Sitic S, Milkovic Perisa M, Suton P and Sarcevic B: The prognostic significance of estrogen receptor $\beta$ in head and neck squamous cell carcinoma. Oncol Lett 12(5): 3861-3865, 2016. PMID: 27895741. DOI: 10.3892/ol.2016.5142

74 Mohamed H, Aro K, Jouhi L, Mäkitie A, Remes S, Haglund C, Atula $\mathrm{T}$ and Hagström $\mathrm{J}$ : Expression of hormone receptors in oropharyngeal squamous cell carcinoma. Eur Arch Otorhinolaryngol 275(5): 1289-1300, 2018. PMID: 29582173. DOI: $10.1007 / \mathrm{s} 00405-018-4949-9$
75 Kano M, Kondo S, Wakisaka N, Wakae K, Aga M, MoriyamaKita M, Ishikawa K, Ueno T, Nakanishi Y, Hatano M, Endo K, Sugimoto H, Kitamura K, Muramatsu M and Yoshizaki T: Expression of estrogen receptor alpha is associated with pathogenesis and prognosis of human papillomavirus-positive oropharyngeal cancer. Int J Cancer 145(6): 1547-1557, 2019. PMID: 31228270. DOI: 10.1002/ijc.32500

$76 \mathrm{Wu}$ TF, Luo FJ, Chang YL, Huang CM, Chiu WJ, Weng CF, Hsu YK and Yuan TC: The oncogenic role of androgen receptors in promoting the growth of oral squamous cell carcinoma cells. Oral Dis 21(3): 320-327, 2015. PMID: 25040852. DOI: 10.1111/odi.12272

77 Liu X, Qing S, Che K, Li L and Liao X: Androgen receptor promotes oral squamous cell carcinoma cell migration by increasing EGFR phosphorylation. Onco Targets Ther 12: 42454252, 2019. PMID: 31239703. DOI: 10.2147/OTT.S200718

78 Tomasovic-Loncaric C, Fucic A, Andabak A, Andabak M, Ceppi M, Bruzzone M, Vrdoljak D and Vucicevic-Boras V: Androgen receptor as a biomarker of oral squamous cell carcinoma progression risk. Anticancer Res 39(8): 4285-4289, 2019. PMID: 31366519. DOI: 10.21873/anticanres.13593

79 Zhan Y, Zhang G, Wang X, Qi Y, Bai S, Li D, Ma T, Sartor O, Flemington EK, Zhang H, Lee P and Dong Y: Interplay between cytoplasmic and nuclear androgen receptor splice variants mediates castration resistance. Mol Cancer Res 15(1): 59-68, 2017. PMID: 27671337. DOI: 10.1158/1541-7786.MCR-160236

80 Hayes DN, Van Waes C and Seiwert TY: Genetic landscape of human papillomavirus-associated head and neck cancer and comparison to tobacco-related tumors. J Clin Oncol 33(29): 32273234, 2015. PMID: 26351353. DOI: 10.1200/JCO.2015.62.1086

81 Nair HB, Luthra R, Kirma N, Liu YG, Flowers L, Evans D and Tekmal RR: Induction of aromatase expression in cervical carcinomas: effects of endogenous estrogen on cervical cancer cell proliferation. Cancer Res 65(23): 11164-11173, 2005. PMID: 16322267. DOI: 10.1158/0008-5472.CAN-05-1087

82 Lubov J, Maschietto M, Ibrahim I, Mlynarek A, Hier M, Kowalski LP, Alaoui-Jamali MA and da Silva SD: Meta-analysis of microRNAs expression in head and neck cancer: uncovering association with outcome and mechanisms. Oncotarget 8(33): 55511-55524, 2017. PMID: 28903437. DOI: 10.18632/oncotarget. 19224

83 Egloff AM, Rothstein ME, Seethala R, Siegfried JM, Grandis JR and Stabile LP: Cross-talk between estrogen receptor and epidermal growth factor receptor in head and neck squamous cell carcinoma. Clin Cancer Res 15(21): 6529-6540, 2009. PMID: 19825947. DOI: 10.1158/1078-0432.CCR-09-0862

84 Lin YC, Wu MH, Wei TT, Chuang SH, Chen KF, Cheng AL and Chen CC: Degradation of epidermal growth factor receptor mediates dasatinib-induced apoptosis in head and neck squamous cell carcinoma cells. Neoplasia 14(6): 463-475, 2012. PMID: 22787428. DOI: 10.1596/neo.12300

85 Jin L, Qi M, Chen DZ, Anderson A, Yang GY, Arbeit JM and Auborn KJ: Indole-3-carbinol prevents cervical cancer in human papilloma virus type 16 (HPV16) transgenic mice. Cancer Res 59(16): 3991-3997, 1999. PMID: 10463597.

86 Sepkovic DW, Stein J, Carlisle AD, Ksieski HB, Auborn K and Bradlow HL: Diindolylmethane inhibits cervical dysplasia, alters estrogen metabolism, and enhances immune response in the K14-HPV16 transgenic mouse model. Cancer Epidemiol 
Biomarkers Prev 18(11): 2957-2964, 2009. PMID: 19861518. DOI: 10.1158/1055-9965.EPI-09-0698

87 Tavassoli M, Soltaninia J, Rudnicka J, Mashanyare D, Johnson $\mathrm{N}$ and Gäken J: Tamoxifen inhibits the growth of head and neck cancer cells and sensitizes these cells to cisplatin inducedapoptosis: role of TGF-beta1. Carcinogenesis 23(10): 15691575, 2002. PMID: 12376463. DOI: 10.1093/carcin/23.10.1569

88 Hoffmann TK, Bojar H, Eckel J, van Lierop A, Balz V, FriebeHoffmann U, Hauser U and Bier H: Effects of tamoxifen on human squamous cell carcinoma lines of the head and neck. Anticancer Drugs 13(5): 521-531, 2002. PMID: 12045464. DOI: 10.1097/00001813-200206000-00011

89 Grünow J, Rong C, Hischmann J, Zaoui K, Flechtenmacher C, Weber KJ, Plinkert P and Hess J: Regulation of submaxillary gland androgen-regulated protein 3A via estrogen receptor 2 in radioresistant head and neck squamous cell carcinoma cells. J Exp Clin Cancer Res 36(1): 25, 2017. PMID: 28166815. DOI: 10.1186/s13046-017-0496-2

90 Li S, Wang B, Tang Q, Liu J and Yang X: Bisphenol A triggers proliferation and migration of laryngeal squamous cell carcinoma via GPER mediated upregulation of IL-6. Cell Biochem Funct 35(4): 209-216, 2017. PMID: 28466560. DOI: 10.1002/cbf.3265

Received May 21, 2021

Revised June 23, 2021

Accepted June 24, 2021 